\title{
sustainability
}

ISSN 2071-1050

www.mdpi.com/journal/sustainability

Article

\section{Chinese Public Willingness to Pay to Avoid Having Nuclear Power Plants in the Neighborhood}

\author{
Chuanwang Sun ${ }^{1}$, Nan Lyu ${ }^{1}$ and Xiaoling Ouyang ${ }^{2, *}$
}

1 Collaborative Innovation Center for Energy Economics and Energy Policy, School of Economics, Xiamen University, Xiamen 361005, China; E-Mails: scw@xmu.edu.cn (C.S.); barcelonana@126.com (N.L.)

2 Department of Economics, Business School, East China Normal University, 500 Dongchuan Road, Shanghai 200241, China

* Author to whom correspondence should be addressed; E-Mail: xlouyang@jjx.ecnu.edu.cn; Tel./Fax: +86-21-5434-4958.

External Editor: Ning Zhang

Received: 30 July 2014; in revised version: 16 September 2014 / Accepted: 23 September 2014 / Published: 17 October 2014

\begin{abstract}
In spite of the decreasing share of nuclear power all over the world, China resumed the approval of large-scale construction of nuclear power plants in 2012 . However, influenced by the worldwide spreading anti-nuclear attitudes, people who live near nuclear power plants showed increasing concerns about nuclear risks. Consequently, the Not In My Backyard (NIMBY) syndrome of nuclear power plants should be evaluated prudently to support the healthy development of nuclear power in China. Based on the face-to-face survey data, this study estimates Chinese public willingness to pay (WTP) to avoid having nuclear power plants in the neighborhood. The respondents include both residents who currently live near and those who would live near nuclear power plants in the future. Considering the possible presence of the sample selection bias caused by protest responses, this paper constructs a two-step sample selection model with the protest responses and the double bounded dichotomous choice (DBDC) questions. Using the Contingent Valuation Method (CVM), we measure the effects of influencing factors of public WTP and study the decay of WTP with longer distances from nuclear power plants. The results suggest that most people are willing to pay higher electricity prices to avoid having nuclear power plants in the neighborhood. Comparing the WTP to avoid having nuclear power plants nearby with
\end{abstract}


the current electricity price, we find that there is an increase of $56.7 \%$ and $69.1 \%$ of respondents' WTP for a nuclear power plant located $80 \mathrm{~km}$ and $30 \mathrm{~km}$, respectively.

Keywords: Not In My Backyard (NIMBY); nuclear power; Contingent Valuation Method (CVM); sustainability

\section{Introduction}

The Fukushima nuclear disaster in 2011 has made severe social, political and economic impacts worldwide, making nuclear power come to the fore as threats to global society [1,2]. Opinion polls show that public support for nuclear power has declined dramatically since the Fukushima nuclear disaster [3]. Public attitude towards nuclear power has played an important role in energy policy-making since the accident, and has made public rejection towards nuclear power a critical problem for nuclear policy all over the world [4], especially for countries with a high density of nuclear power reactors and extensive operational experience of nuclear power plants [5]. Most public protests can be attributed to the Not In My Backyard (NIMBY) attitude regarding nuclear power facilities. This phenomenon, which has been widely reported [6-9], is the case that the construction of new nuclear facilities is often strongly opposed by residents who live in the neighborhood [10]. Due to the sharp decline of public acceptance, the share of nuclear power in electricity generation decreased from $16.8 \%$ in 2011 to $13.5 \%$ in 2012 [11]. For example, Japan has shut all 50 nuclear power plants down. Countries such as Germany, Switzerland and Belgium have confirmed the closing-down policies under the public pressure [12].

By contrast, China has the most ambitious nuclear expansion plan after the Fukushima nuclear disaster [13]. The government has showed determinations to accelerate the development of nuclear power. Specifically, by the end of 2014, China would increase 8.64 gigawatt-electric (GWe) of nuclear power installed capacity, three times the increment in 2013 [14]. According to the National Nuclear Long-and-medium Term Development Planning (2011-2020) [15], China plans to realize 88 GWe of nuclear power installed capacity by 2020 . This goal implies that nuclear power in China will exceed the total electricity consumption in Canada in 2012 [16]. More long-term plans for future capacity are 200 GWe by 2030 and 400 GWe by 2050 [17]. Most of China's nuclear power reactors are located in the coastal regions, which involves only $5.8 \%$ of the whole population [18] and small towns and cities. In addition, nuclear power generation only accounts for $2.1 \%$ of total power generation in China [19], far below the world average level (11\%) [20]. According to the research by Nature News in cooperation with Columbia University [21], 75 million people live near 49 nuclear power reactors in China, which includes nuclear power plants under construction and in operation, and the distances are in the range of 75 kilometers $(\mathrm{km})$. Different from the anti-nuclear activities in other countries, in the past, nuclear power plants did not have a wide impact in China in view of the large population base and vast land. However, we should note that China is currently facing a rapid nuclear power expansion (13 times the current installed nuclear power capacity by 2050) [22]. Considering that the nuclear power installed capacity will be twice as great as before, and China will expand nuclear power from coastal to inland regions in the near future, the number of residents who live near nuclear power plants will have a rapid growth. After the Fukushima nuclear disaster, the voice of anti-nuclear seems to be louder, especially 
from those who live in the neighborhood. People living nearby have, apparently, shown their anxiety [23]. There have been several anti-nuclear activities in local areas in recent years, which have affected the attitude of people who live in other places of China. Hence, a concern is provoked that China's nuclear expansion could possibly lead to a more severe NIMBY attitude among the public, as more residents and regions will be affected. This attitude in turn may have a negative impact on nuclear power expansion in the future. To summarize, studies of Chinese public willingness to pay to avoid having nuclear power stations in the neighborhood are believed to be mandatory.

The NIMBY phenomena are highly complex, representing a wide range of facilities and participants [24]. There are definite regulations about the location and safe distance of NIMBY facilities in many countries [25], but evaluation of safety distance by residents in terms of the vicinity of the facilities is always greater than that identified by the government. Similar to nuclear power plants, paraxylene (PX, a chemical essential) plants are also NIMBY facilities, which have been strongly opposed by the general public in China in recent years. PX plants are common in many countries [26], which are usually kept $4 \mathrm{~km}$ away from the city center in Korea [27], and $5 \mathrm{~km}$ from the city center in Singapore [28]. However, a planned PX project with a distance of $7 \mathrm{~km}$ from the city center in Xiamen was stopped because of the public protest. This phenomenon shows that the distance by regulation doesn't fall in line with the accepted distance by the public. In this context, this study tries to find out how the public reacts to the location of a new nuclear power plant in the distance of $30 \mathrm{~km}$ and $80 \mathrm{~km}$ separately, based on data from the survey of China's Public Perception of Nuclear Power (CPPNP). The survey of CPPNP, launched by China Center for Energy Economics Research at Xiamen University once or twice a year from 2013, is a nationwide face-to-face survey focuses on the public perception of nuclear power.

This paper attempts to answer three questions as follows:

First, is there a NIMBY attitude towards nuclear power plants among residents in China, including both the residents who currently live near and those who will live near the plants in the future? How do socio-economic characteristics, such as income, age and gender, affect Chinese public willingness to pay to avoid having nuclear power stations in the neighborhood?

Second, will residents show different WTP at different construction phases of the NIMBY facilities? In our study, we explore this by evaluating and comparing the WTP of residents who live in coastal areas where nuclear power plants have already constructed, and those who live in inland areas where nuclear power plants would be built in the future.

Third, how does the public WTP change with the dwelling distance from nuclear power plants? What's the residents' estimated safety distance from nuclear power plants? Does the safety distance accepted by the public fall in line with that regulated by the government?

The remainder of this paper is organized as follows. Section 2 reviews the main research on NIMBY of nuclear power plants and the evaluation methods of WTP. Section 3 describes the data from CPPNP and the methodological approach used in this study, which corrects the possible selection bias due to protest responses. Section 4 presents the empirical results, in which we analyze public WTP by answering the three questions above. Finally, Section 5 provides conclusions and gives policy suggestions. 


\section{Literature Review}

\subsection{Research of Public Attitude towards Nuclear Power}

Considering the global environmental and economic development [29,30], nuclear energy has been attached worldwide attention to its impacts on greenhouse gases emissions reduction [13,31,32]. However, the Fukushima nuclear disaster reminds the public to refocus on the risks of nuclear power [33], and pay more attention to nuclear policies [34]. Plenty of research has investigated risk perceptions associated with nuclear power [1,25,35-37]. For example, Kim et al. [35] examined the effects of knowledge, trust, risk and benefit-related factors on the public acceptance of nuclear power across 19 countries, and found that trust in inspection authorities was crucial for the decision between opposition and reluctant acceptance. Some researchers analyzed the nuclear energy policies and strategies in the future [12,38-43]. Aoki and Rothwell [39] analyzed the causes, responses and consequences of the Fukushima nuclear disaster by comparing them with those of the Three Mile Island and the Chernobyl, and suggested the introduction of an independent Nuclear Safety Commission. Other scholars explored the public acceptance and change of attitudes toward nuclear power and other renewable energy [44-46]. For instance, using a longitudinal study design, Siegrist and Visschers [44] found that the Fukushima nuclear disaster had a negative impact on the acceptance of nuclear power.

NIMBY is an important public attitude, which has attracted increasing attentions from scholars. The NIMBY syndrome is an evidence for the opposition to the local siting of nearly all-environmental and technological hazards [47]. The public attitude of NIMBY indicates that certain services are in principle beneficial to the majority of the population, but are in practice often strongly opposed by local residents who live near the proposed facilities [48]. Since China has resumed the approval of new nuclear power plants, the NIMBY attitude about nuclear power would be an urgent problem for China. Research about public attitudes toward nuclear power after the Fukushima nuclear disaster is relatively scarce in China. He et al. [10] analyzed public participation and trust in nuclear power development by investigating residents who live near the Haiyang nuclear power plant in China. Results indicated that the Chinese respondents had a high level of trust in governmental authorities rather than in nuclear power companies and the media. Results also demonstrated that respondents with lower levels of education were more convinced by government information and had more confidence in government response capacities. Zhang and Tong [49] comprehensively analyzed factors that affect NIMBY attitude towards nuclear power plants, and showed that residents who lived near nuclear power plants had strong NIMBY attitudes after the Fukushima nuclear disaster, and the main concerns included health risk, long-term risks and economic benefits. Studies of both He et al. [10] and Zhang and Tong [49] only focused on residents who live near the existing nuclear power plants and excluded residents who lived far away from the plants. With the rapid development of nuclear power, some residents who currently live far away from the plants may be adjacent to the plants in the future; hence, it is inaccurate to measure public perceptions with only residents who live near the nuclear power plants. Our study tries to contribute to literatures by including both residents in the evaluation of public WTP to avoid having nuclear power stations in the neighborhood. Although Zhang and Tong [49] explored the respondents' perception on the distances of nuclear power plants, they paid more attention to affecting factors of the living distance. 
Our study also tries to figure out the change of WTP with longer living distances to analyze the relationship between the living distance and NIMBY attitude more precisely.

\subsection{Methods of Testing the NIMBY Syndrome}

Few studies covered the issue of NIMBY syndrome after the Fukushima nuclear disaster [50]. Before that, plenty of studies had investigated the WTP to avoid having NIMBY facilities constructed in the neighborhood [51]. The analysis methods can be divided into two categories: the qualitative attitude analysis and the quantitative numerical estimate.

Many scholars analyzed the NIMBY syndrome by attitude analysis [25,48,52], of which, the investigations covered many aspects including the public risk perception, the cognition degree, distance, and individual characteristics such as age, gender, income, education, and so on. Qualitative attitude analysis is a basic analysis in the research of NIMBY syndrome, which directly collects and truly presents respondents' attitudes with little bias. Conclusions of the above studies showed how distance affects residents' attitude towards the NIMBY facilities. Several studies showed that people who lived near the nuclear power plant of Three Mile Island had stronger stress reactions than people who lived far away [53,54]. Huppe and Weber [52] found an inverted U-shaped relationship between the strength of opposition towards nuclear power plants and the distance of dwelling place to the plant. The above studies focused on residents who lived near the nuclear power plants for many years, but overlooked the time factor (which is a key element that differentiates public attitudes [55]). More research showed that opposition would be the strongest at the planning phase, and would be weaker before a project was proposed or after the facility was in operation [56]. The apparent "gap" in attitudes between "before" and "during" the planning of a local project is a key problem [57]. Hence, our study selects samples including both the areas with nuclear power plants and those nuclear power plants will be built in the future.

Researchers also tried to quantify the NIMBY syndrome and evaluate the scale and intensity of protests provoked by facilities that perceived to be risky [58]. They made use of property values or willingness to pay (WTP)/willingness to accept (WTA) of the public [59-61]. For example, Ansolabehere and Konisky [51] measured the public attitude towards nuclear power construction, and found that most Americans oppose having nuclear power plants in their neighborhood. Gawande and Jenkins-Smith [62] found that being five miles away from a nuclear waste shipment route means a $3 \%$ increase of average house value compared to properties right on the route. However, Zweifel et al. [63] questioned the approach of testing the NIMBY syndrome based on real estate property values. They pointed out that the estimates of individual WTP based on the analysis of the compensating differentials found in market data would be distorted and incomplete, because market prices depend on demand and supply, which in turn made the results affected by zoning laws and building regulations. Therefore, the Contingent Valuation Method (CVM) had been used by researchers to estimate public willingness to pay (WTP) or willingness to accept (WTA) [63-65]. CVM is a method designed to elicit preference [66]. It is a stated-preference valuation method that directly surveys individuals or households to estimate the values of non-market goods or services [64]. Respondents are asked to state their WTP for an improvement of a public good (i.e., environmental quality) or the avoidance of a public "bad" (i.e., risks or pollution) in a hypothetical market. In this way, researches can evaluate some non-market goods such as public defense, environmental amenities, death risks reduction and so on [67]. Zweifel et al. [63] investigated residents' 
WTP for risk reduction of nuclear power plants nearby, and found a linear relation between the WTP and the distance. Studies about waste disposal facilities mainly focused on the WTP analysis to quantify NIMBY. For instance, Ferreira and Gallagher [64] chose the WTP and the WTA to analyze using host community compensation to solve the NIMBY issue, and found that the WTP was lower than the WTA. Pelekasi et al. [68] presented a contingent valuation survey aimed at investigating a local community's willingness to accept (WTA) compensation for allowing the establishment and operation of a marble quarry nearby and exploring the determinants of NIMBY reactions against the marble quarrying activity. Zhou et al. [65] focused on residents' WTA of the compensation in waste incineration facilities in China. They emphasized that standardized management, publicity mechanism, and whole-process supervision should be built. In this way, the ecological compensation can turn the NIMBY attitude into acceptation. According to the previous studies on the WTP, factors, such as gender, age, income, education, distance, risk perception, trust, etc., have effects on the public WTP. Therefore, our study chooses some of these factors to investigate how they affect Chinese WTP to avoid having nuclear power plants in the neighborhood. Table 1 shows results of relative research publications briefly.

Table 1. Main previous research publications of the NIMBY syndrome.

\begin{tabular}{|c|c|c|c|c|}
\hline Author & Country & Method & Factor & Result \\
\hline $\begin{array}{l}\text { Huppe and } \\
\text { Weber [52] }\end{array}$ & Germany & $\begin{array}{l}\text { Attitude } \\
\text { analysis }\end{array}$ & $\begin{array}{c}\text { Distance, Age, } \\
\text { Gender }\end{array}$ & $\begin{array}{l}\text { An inverted U-shaped relationship between } \\
\text { firmness of negative attitudes toward nuclear } \\
\text { power plants and the distance of dwelling to } \\
\text { the plant. }\end{array}$ \\
\hline $\begin{array}{l}\text { Gawande and } \\
\text { Jenkins-Smith } \\
\text { [62] }\end{array}$ & US & $\begin{array}{c}\text { Hedonic } \\
\text { model }\end{array}$ & $\begin{array}{l}\text { Distance, Age } \\
\text { of residence, } \\
\text { Race, } \\
\text { Education, } \\
\text { Income, etc. }\end{array}$ & $\begin{array}{l}\text { Being five miles away from a nuclear waste } \\
\text { shipment route was associated with a } 3 \% \\
\text { increase of average house value compared to } \\
\text { the property on the route. }\end{array}$ \\
\hline $\begin{array}{l}\text { Zweifel et al. } \\
{[63]}\end{array}$ & Switzerland & WTP & $\begin{array}{l}\text { Distance, } \\
\text { Attitude, } \\
\text { Gender, } \\
\text { Income, etc. }\end{array}$ & $\begin{array}{l}\text { For residents who live at the power plant, the } \\
\text { maximum of lifetime WTP is } \$ 2280 \text {. } \\
\text { It decreases by } \$ 24 \text { per km, or } \$ 15 \text { per mile. }\end{array}$ \\
\hline $\begin{array}{c}\text { Van der Horst } \\
{[48]}\end{array}$ & UK & $\begin{array}{l}\text { Attitude } \\
\text { analysis }\end{array}$ & $\begin{array}{l}\text { Distance, } \\
\text { Time, etc. }\end{array}$ & $\begin{array}{l}\text { Proximity does have a strong influence on } \\
\text { public attitudes toward the proposed NIMBY } \\
\text { projects. However, the nature, strength and } \\
\text { spatial scale of this effect may vary according } \\
\text { to the local context and value of the land. }\end{array}$ \\
\hline $\begin{array}{c}\text { Greenberg } \\
{[25]}\end{array}$ & US & $\begin{array}{l}\text { Attitude } \\
\text { analysis }\end{array}$ & $\begin{array}{l}\text { Distance, Age, } \\
\text { Race, Worry, } \\
\text { Trust, Income, } \\
\text { etc. }\end{array}$ & $\begin{array}{l}\text { More than half of the respondents who live near } \\
\text { the nuclear power plants oppose constructing } \\
\text { more nuclear power plants nearby. }\end{array}$ \\
\hline $\begin{array}{c}\text { Ferreira and } \\
\text { Gallagher [64] }\end{array}$ & Ireland & $\begin{array}{l}\text { WTP/ } \\
\text { WTA }\end{array}$ & $\begin{array}{l}\text { Gender, } \\
\text { Occupation, } \\
\text { Dwelling } \\
\text { breakdown, } \\
\text { Education, etc. }\end{array}$ & $\begin{array}{l}\text { The rejection rates for WTA CV study with } \\
\text { between } 78 \% \text { and } 91.5 \% \text { of respondents } \\
\text { rejecting the offer of compensation. Most } \\
\text { rejections are protest responses (which range } \\
\text { between } 65 \% \text { and } 90.3 \% \text { of the zero responses). }\end{array}$ \\
\hline
\end{tabular}


Table 1. Cont.

\begin{tabular}{|c|c|c|c|c|}
\hline Author & Country & Method & Factor & Result \\
\hline $\begin{array}{l}\text { Zhang and } \\
\text { Tong [49] }\end{array}$ & China & $\begin{array}{c}\text { Regression } \\
\text { analysis }\end{array}$ & $\begin{array}{c}\text { Distance, } \\
\text { Age, } \\
\text { Gender, } \\
\text { Education, } \\
\text { Risk, } \\
\text { Benefit, etc. }\end{array}$ & $\begin{array}{l}80.2 \% \text { of respondents were against nuclear } \\
\text { power construction in their neighborhood; } \\
78.7 \% \text { of respondents proposed that nuclear } \\
\text { power plants should be constructed in other } \\
\text { provinces which are far away from the places } \\
\text { they live; } 33.1 \% \text { of respondents planed to } \\
\text { relocate if there were nuclear power plants in } \\
\text { their neighborhood. Health risks, long-term } \\
\text { hazards and benefits are three critical factors } \\
\text { of their concerns. }\end{array}$ \\
\hline
\end{tabular}

Quantitative numerical estimates of the Chinese public WTP to avoid having nuclear power plants in the neighborhood are still scarce. We intend to make contributions to literature in this filed. In this paper, we analyze residents' WTP for other high-cost clean energies [69] to replace nuclear power. Since respondents have to be definite about their WTP, they are required to be more rational in measuring both the risks and benefits of nuclear power plants. Unlike the previous efforts to quantify the NIMBY syndrome, our study explores the decay of NIMBY associated with distance to analyze the difference between public acceptable living distance and the distance proposed by safety regulations of nuclear power. Considering that the inevitable NIMBY attitudes at the planning phase, we collect samples in the areas where nuclear power plants will be built in the future to compare their NIMBY attitudes with those of the respondents who currently live near nuclear power plants. Our study can also be an important reference for further studies about the time factor of NIMBY, as well as a part of the temporal extent of studies with regard to nuclear power plants (before people are informed about the plan, during the planning process, or after the plant has in operation) [48].

It should be noted that Contingent Valuation Method (CVM) typically uses survey techniques to elicit individuals' willingness to pay (WTP) for the hypothetical provision of a public good (or environmental good) or willingness to accept (WTA) compensation for the hypothetical loss of this good. Both of the estimation methods are common. Literature, such as Saz-Salazar et al. [60] and Carson [61], has compared WTA and WTP in detail. The data used in this paper are from the CPPNP, which gathers information by asking questions of WTP.

\section{Methods and Data}

\subsection{Two-Step Sample Selection Model}

CPPNP is a systematic survey of public attitudes about nuclear power in China (The specific introduction of CPPNP can be found in Appendix). The survey of CPPNP uses dichotomous choice (DC) format questions to obtain the WTP for replacing nuclear power nearby, because the DC format has been frequently used in the literature [70]. Respondents may refuse to accept bids for elicitation questions for reasons that differ from the genuine zeros $[71,72]$. Considering the possible presence of the sample selection bias caused by protest responses, this paper constructs a two-step sample selection model with the protest responses and the double bounded dichotomous choice (DBDC) questions. 
Protest responses can be reflected by a system of two-step sequential questions in the survey of CPPNP. The first-step is that, before asking the DBDC question, we ask each respondent an initial question (sample selection question, SSQ), which is, if he or she were willing to use other clean energies to replace nuclear power stations in his or her neighborhood by paying higher electricity tariffs (The specific structure of the questionnaire can be found in Appendix). After obtaining answers of the first question from the respondents, we set two situations in the second-step. One situation is that if the respondents replied "Yes" to the first question, a follow up DBDC question would be posed to elicit the WTP. That is, the respondents should reply that whether their WTP equals or exceeds a sequence of two bids. If respondents' WTP is lower than the first bid, investigators will ask the question again with a smaller bid. On the contrary, if the WTP were equal to or higher than the first bid, the second bid would be higher. The other situation is that if the respondents replied "No" to the first question, investigators would further inquire the motives behind their answers. The above treatment can be used to determine whether the respondents are with genuine zeros or with protest responses (The specific questions can be found in Appendix). Finally, we discuss the difference between the WTP of nuclear power plants located $80 \mathrm{~km}$ and the WTP of nuclear power plants located $30 \mathrm{~km}$ in the neighborhood. Figure 1 illustrates the process of the two-step sample selection.

Figure 1. The schematic diagram of sample selection and DBDC questions.

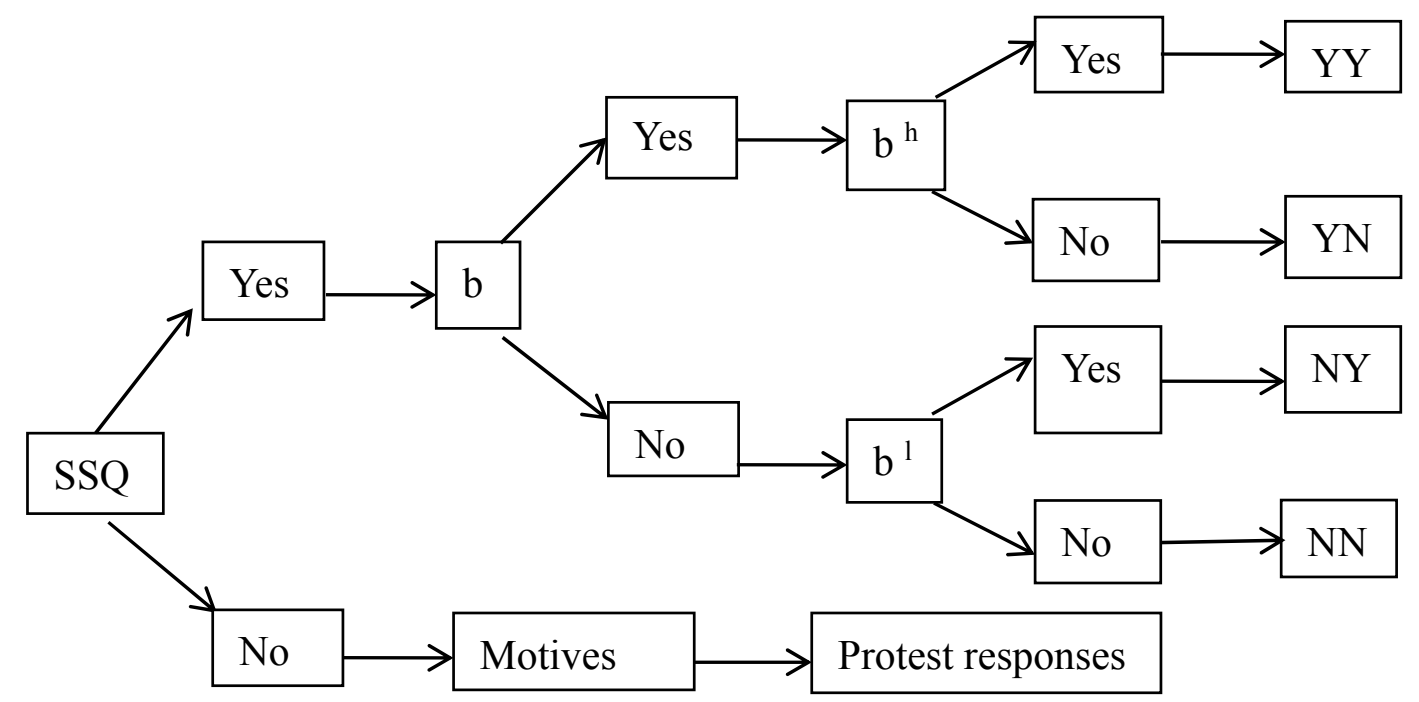

According to studies of Heckman [73], Calia and Strazzera [74], and Ramajo-Hernández and Saz-Salazar [72], two-step sequential questions can be modeled by the following two equations: the first one is the selection equation, and the second one is the elicitation equation.

For each respondent, the binary variable $Y_{i}$ can be defined by the selection equation, which represents whether or not the respondent $i$ has protest responses. In turn, the latent variable $Y_{1}^{*}$ can be represented:

$$
\begin{gathered}
Y_{i}=\left\{\begin{array}{cc}
1, & \text { if } Y_{i}^{*} \geq 0, \quad i \text { without protest responses } \\
0, & \text { if } Y_{i}^{*}<0, \quad i \text { with protest responses }
\end{array}\right. \\
Y_{i}^{*}=\alpha_{1}+w_{i}^{\prime} \gamma+v_{i}
\end{gathered}
$$


where $\alpha_{1}$ is the constant item in the selection equation, vector $w_{i}$ represents factors that influence the probability of giving protest responses from respondents, and $\gamma$ is the vector of estimated parameter in the selection equation. According the pilot study for the pre-test survey, we commonly assume that the error term $v_{i}$ has a normal distribution with mean zero [73], thus, the selection equation of $Y_{i}$ is the probit model, and $P\left(Y_{i}=1 \mid \alpha_{1}, w_{i}\right)=\Phi\left(\alpha_{1}+w_{i}^{\prime} \gamma\right)$.

We define that the $W T P_{i}$ represents the willingness to pay of each respondent, and whether the $W T P_{i}$ can be observed depends on whether $Y_{1}$ equals 1.

$$
W T P_{i}= \begin{cases}\text { Observable, } & \text { if } Y_{i}=1 \\ \text { Unobservable, } & \text { if } Y_{i}=0\end{cases}
$$

The zero choice of $Y_{i}$ is a threshold for the available data of $W T P_{i}$.

The WTP function (elicitation equation) are represented below:

$$
W T P_{i}=\alpha_{2}+z_{i}^{\prime} \beta+u_{i}
$$

In that case, the respondent will say "Yes" only when his true $W T P_{i}$ is higher than the given bid. $\alpha_{2}$ is the constant item in the elicitation equation, $z_{i}$ is a vector of explanatory variables affecting the value of $W T P_{i}, \beta$ is a vector of parameters, the error term $u_{i}$ has a normal distribution with mean zero.

Considering the sample selection bias caused by protest responses, the conditional expectation can be expressed as:

$$
\begin{aligned}
E\left(W T P_{i} \mid \text { Observable }\right) & =E\left(W T P_{i} \mid Y_{i}^{*} \geq 0\right) \\
& =E\left(\alpha_{2}+z_{i}^{\prime} \beta+u_{i} \mid \alpha_{1}+w_{i}^{\prime} \gamma+v_{i}>0\right) \\
& =E\left(\alpha_{2}+z_{i}^{\prime} \beta+u_{i} \mid v_{i}>-\alpha_{1}-w_{i}^{\prime} \gamma\right) \\
& =\alpha_{2}+z_{i}^{\prime} \beta+E\left(u_{i} \mid v_{i}>-\alpha_{1}-w_{i}^{\prime} \gamma\right)
\end{aligned}
$$

Under the assumption that the error terms are jointly normal, and according to the expectation formula of incidental truncation [74], we have:

$$
E\left(W T P_{i} \mid Y_{i}^{*} \geq 0\right)=\alpha_{2}+z_{i}^{\prime} \beta+\rho \sigma_{u} \lambda\left(-\alpha_{1}-w_{i}^{\prime} \gamma\right)
$$

where $\rho$ is the correlation between $u_{i}$ and $v_{i}, \sigma_{u}$ is the standard deviation of $u$, and $\lambda\left(-\alpha_{1}-w_{i}^{\prime} \gamma\right)$ is the Inverse Mill's Ratio (IMR).

Obviously, under the condition of taking the sample selection bias into consideration, if we use $E\left(W T P_{i}\right)=\alpha_{2}+z_{i}^{\prime} \beta$ directly to estimate the sample data, the omitted item $\rho \sigma_{u} \lambda\left(-\alpha_{1}-w_{i}^{\prime} \gamma\right)$ will be resulted. Generally, $w_{i}$ and $z_{i}$ will include the same variables, therefore, they may probably correlated. Only under the condition of $\rho=0$, estimates can be consistent by directly estimating the elicitation equation of the omitted item IMR. Therefore, it is necessary to use the two-step sample selection model and address the possible presence of self-selection caused by protest responses [72].

The specific estimation method for the two-step sample selection model is as follows: the first step is obtaining $\alpha_{1}$ and $\gamma$ by estimating the selection equation $P\left(Y_{i}=1 \mid \alpha_{1}, w_{i}\right)=\Phi\left(\alpha_{1}+w_{i}^{\prime} \gamma\right)$, and $\lambda(\bullet)$ (IMR); the second step is estimating the elicitation equation and including $\lambda(\bullet)$ as an additional 
explanatory variable. Therefore, the elicitation equation can be rewritten as the following format. And testing the null that the coefficient $\theta$ on $\lambda(\bullet)$ is zero is equivalent to testing for sample selection bias.

$$
W T P_{i}=\alpha_{2}+z_{i}^{\prime} \beta+\theta \lambda(\bullet)+u_{i}
$$

The elicitation question in this paper adopts the DBDC format. According to Liao et al. [75] and Jun et al. [76], the bid price is offered twice in the DBDC question model, and the second bid price is determined by the answer of the first bid $b$. If the answer is "Yes" for the first question, a higher bid $b^{h}$ will be given; otherwise, a lower bid $b^{l}$ will be given.

In this way, there are four categories of WTP:

(1) The answers are both "No" for two bids: $W T P<b^{l}, P_{N N}$ is the corresponding probability.

(2) The answer is "No" for the first bid, and "Yes" for the second bid: $b^{l} \leq W T P<b, P_{N Y}$ is the corresponding probability.

(3) The answer is "Yes" for the first bid, and "No" for the second bid: $b \leq W T P<b^{h}, P_{Y N}$ is the corresponding probability.

(4) The answers are both "Yes" for both the first and the second bids: $b^{h} \leq W T P<\infty, P_{Y Y}$ is the corresponding probability.

Since $u_{i}$ with a normal distribution, the DBDC elicitation equation can be estimated by the Probit model which includes the additional explanatory variables $b, b^{h}$ and $b^{l}$. The probability functions are denoted as:

$$
\begin{aligned}
& P_{N N}=1-\Phi\left(\frac{\alpha_{2}+z_{i}^{\prime} \beta+\theta \lambda(\bullet)}{\sigma_{u}}-\frac{b^{l}}{\sigma_{u}}\right) \\
& P_{N Y}=\Phi\left(\frac{\alpha_{2}+z_{i}^{\prime} \beta+\theta \lambda(\bullet)}{\sigma_{u}}-\frac{b^{l}}{\sigma_{u}}\right)-\Phi\left(\frac{\alpha_{2}+z_{i}^{\prime} \beta+\theta \lambda(\bullet)}{\sigma_{u}}-\frac{b}{\sigma_{u}}\right) \\
& P_{Y N}=\Phi\left(\frac{\alpha_{2}+z_{i}^{\prime} \beta+\theta \lambda(\bullet)}{\sigma_{u}}-\frac{b}{\sigma_{u}}\right)-\Phi\left(\frac{\alpha_{2}+z_{i}^{\prime} \beta+\theta \lambda(\bullet)}{\sigma_{u}}-\frac{b^{h}}{\sigma_{u}}\right) \\
& P_{Y Y}=\Phi\left(\frac{\alpha_{2}+z_{i}^{\prime} \beta+\theta \lambda(\bullet)}{\sigma_{u}}-\frac{b^{h}}{\sigma_{u}}\right)
\end{aligned}
$$

Here, we obtain the estimated parameters using the maximum likelihood estimation (MLE). The log-likelihood function that needs to be maximized is:

$$
\ln L=\sum_{i=1}^{N}\left(I_{i}^{Y Y} \ln P_{Y Y}+I_{i}^{Y N} \ln P_{Y N}+I_{i}^{N Y} \ln P_{N Y}+I_{i}^{N N} \ln P_{N N}\right)
$$

where $I_{i}^{Y Y}, I_{i}^{Y N}, I_{i}^{N Y}, I_{i}^{N N}$ are index variables, which will be 1 when the answer from respondent $i$ is "Yes"-“Yes", "Yes"-“No", "No"-"Yes", "No"-“No" to each bid price, respectively; otherwise, will be zero. Once the estimated parameters are obtained, we can estimate the fitted value of WTP (for a detailed description of the DBDC model, please see Jun et al. [76]). 


\subsection{Variables and Data Source}

Variables and data used in this paper are based on the survey of CPPNP, of which the main structure can be found in Appendix. The explanatory variables in this study include the socio-economic characteristics of respondents such as gender, age, educational level (have a bachelor degree or not), income level, job (a civil servant or not), and whether the concerns of nuclear power come from the subjective pressures. The explanatory variables and their main descriptive statistics are listed in Table 2. These characteristics are considered being related with respondents' protest responses and the WTP. The gender ratio is kept close to balance with $52.19 \%$ of male and $47.81 \%$ of female. The size of the sample is 799 .

Table 2. Explanatory variable descriptions and statistics.

\begin{tabular}{clcccc}
\hline Variable & \multicolumn{1}{c}{ Description } & Mean & Standard deviation & Min & Max \\
\hline Gender & Dummy variable (male =1) & 0.522 & 0.500 & 0 & 1 \\
Age & Respondents' age & 35.73 & 8.469 & 18 & 65 \\
College & Dummy variable (have a bachelor degree =1) & 0.427 & 0.495 & 0 & 1 \\
Income & Net annual personal income (10,000 USDs) & 0.824 & 0.600 & 0.080 & 4.013 \\
Job & Dummy variable (a civil servant = 1) & 0.239 & 0.427 & 0 & 1 \\
Risk & Dummy variable (from subjective pressures =1) & 0.063 & 0.242 & 0 & 1 \\
\hline
\end{tabular}

The survey data indicate that a part of respondents were unwilling to pay higher electricity tariffs to replace nuclear power plants nearby by using other clean energies. Table 3 shows the questions concerning the sample selectivity, and data of the motives behind a "No" WTP response. Specifically, when the scenario assumption in the sample selection question (SSQ) of CVM is "replacing the nuclear power plant located $80 \mathrm{~km}$ in the neighborhood", 199 respondents are unwilling to pay. In which, responses of 91 respondents (45.7\%) are genuine zeros, indicating that nuclear power and other clean energies are indifferent to them, and thus they accept the construction of nuclear power rather than paying higher electricity tariffs. However, responses of 108 respondents $(54.3 \%)$ are protest responses in which, 72 respondents hold the views that the government should be responsible for the issue, and 36 respondents believe that they had already paid enough fees or taxes, and, therefore, are unwilling to pay more.

However, when the scenario assumption in the sample selection question (SSQ) of CVM is "replacing the nuclear power plant located $30 \mathrm{~km}$ in the neighborhood", only 97 respondents are unwilling to pay. The results are much smaller compared to the nuclear power plant that located $80 \mathrm{~km}$ in the neighborhood. In which, responses of 82 respondents are genuine zero responses, while only 15 responses are protest responses. Results indicate that, respondents are more willing to pay when the distance of nuclear power plants is shortened from $80 \mathrm{~km}$ to $30 \mathrm{~km}$. Particularly, the number of protest responses reduced dramatically when the distance of nuclear power plants is shorter. The difference in acceptance level that reflected by different distance indicates the existence of the NIMBY syndrome. In other words, people have higher willingness to pay to replace nuclear power when the location of nuclear power plants is quite close.

On the basis of evaluating WTP using the two-step sample selection model, we set three models to analyze the NIMBY attitude towards nuclear power plants in China. Model 1 describes residents' WTP for avoiding a new nuclear power plant located $80 \mathrm{~km}$ in the neighborhood and the factors affecting their WTP. Model 2 describes residents' WTP for avoiding a new nuclear power plant located $30 \mathrm{~km}$ in the 
neighborhood and the factors affecting their WTP. In Model 3, we analyze the difference of NIMBY attitudes between inland areas and coastal areas.

Table 3. The motives for a "No" WTP response.

\begin{tabular}{|c|c|c|c|}
\hline The condition of distance & Motives & Description & Number \\
\hline \multirow[t]{4}{*}{$\begin{array}{l}\text { Are you willing to pay higher electricity } \\
\text { tariffs in order to substitute the } \\
\text { nuclear power plant located } 80 \mathrm{~km} \\
\text { in the neighborhood by using other } \\
\text { clean energies? }\end{array}$} & $\begin{array}{l}\text { Genuine zero } \\
\text { responses }\end{array}$ & $\begin{array}{l}\text { I am indifferent to nuclear power; } \\
\text { therefore, I am unwilling to pay } \\
\text { an extra amount of money. }\end{array}$ & 91 \\
\hline & $\begin{array}{l}\text { Protest } \\
\text { responses }\end{array}$ & $\begin{array}{l}\text { The government should be } \\
\text { responsible for the issue. }\end{array}$ & 72 \\
\hline & & $\begin{array}{l}\text { I have paid enough costs } \\
\text { and taxes, and therefore } \\
\text { I do not want to pay more. }\end{array}$ & 36 \\
\hline & Total number & & 199 \\
\hline \multirow{4}{*}{$\begin{array}{l}\text { Are you willing to pay higher electricity } \\
\text { tariffs in order to substitute the nuclear } \\
\text { power plant located } 30 \mathrm{~km} \text { in the } \\
\text { neighborhood by using other } \\
\text { clean energies? }\end{array}$} & $\begin{array}{l}\text { Genuine zero } \\
\text { responses }\end{array}$ & $\begin{array}{l}\text { I am indifferent to nuclear power; } \\
\text { therefore, I am unwilling to pay an } \\
\text { extra amount of money. }\end{array}$ & 82 \\
\hline & $\begin{array}{c}\text { Protest } \\
\text { responses }\end{array}$ & $\begin{array}{l}\text { The government should be } \\
\text { responsible for the issue. }\end{array}$ & 9 \\
\hline & & $\begin{array}{l}\text { I have paid enough costs and taxes, and } \\
\text { therefore I do not want to pay more. }\end{array}$ & 6 \\
\hline & Total number & & 97 \\
\hline
\end{tabular}

The choices of $30 \mathrm{~km}$ and $80 \mathrm{~km}$ as signifying site regions in the survey of CPPNP were made on the basis of comprehensive discussions. According to United States Nuclear Regulatory Commission (U.S.NRC) [77], in order to facilitate a preplanned strategy for protective actions during an emergency, there are two emergency planning zones (EPZs) around each nuclear power plant, and the range of EPZ is 50 miles regulated by U.S.NRC. Table 4 shows the EPZs of three main nuclear power plants in China. The survey chooses $30 \mathrm{~km}$ and takes the EPZs of China's nuclear power plants as references. Moreover, Greenberg et al. [25] also choose 50 miles to signify a nuclear power site region when exploring the NIMBY syndrome in the USA. A distance of $80 \mathrm{~km}$ is suggested as the range of site evaluation of nuclear power plant by the International Atomic Energy Agency (IAEA) [78] after the Fukushima nuclear disaster. Beyond $80 \mathrm{~km}$, there are no regulations for implementing emergency measures. Thus, $30 \mathrm{~km}$ and $80 \mathrm{~km}$ in the survey of CPPNP offer reasonable references in investigating the relationship between distance and residents' NIMBY attitudes. If respondents were willing to pay for other clean energies so as to avoid having a new nuclear power plant in the neighborhood, we can regard there exist the syndrome of NIMBY. 
Table 4. The rules of EPZ of three nuclear power plants in China.

\begin{tabular}{ccccc}
\hline Zone & Da Yawan & Qinshan & Tianwan \\
\hline \multirow{2}{*}{ Plume Exposure Pathway EPZ } & I & $0-5 \mathrm{~km}$ & $0-3 \mathrm{~km}$ & $0-4 \mathrm{~km}$ \\
& II & $5-10 \mathrm{~km}$ & $3-7 \mathrm{~km}$ & $4-8 \mathrm{~km}$ \\
\hline Ingestion Exposure Pathway EPZ & $0-50 \mathrm{~km}$ & $0-30 \mathrm{~km}$ & $0-25 \mathrm{~km}$ \\
\hline \multicolumn{2}{c}{ Note: Data in Table 4 are collected from the research of Zhao et al. (2003) [79]. }
\end{tabular}

\section{Results and Discussion}

\subsection{NIMBY Attitude towards Nuclear Power Plants and Its Influencing Factors}

Results of Model 1 and Model 2 are shown in Table 5. From the results of the first step (sample selection equation, SSQ), we can see that in Model 1, the probability of willingness to replace nuclear power by paying for higher electricity tariffs is higher for respondents with high-income and have college degrees. Moreover, respondents who are worried about the subjective risks of nuclear power are more likely to give protest responses. In addition, factors such as gender, age and job have no significant effects on the probability of giving protest responses. However, in Model 2, all results of the sample selection equation are insignificant.

The comparison of results of Model 1 and Model 2 indicate that some of these explanatory variables can significantly influence the probability of giving protest responses from respondents under the scenario of constructing a nuclear power plant that located $80 \mathrm{~km}$ in the neighborhood. However, when the scenario changes to be constructing a nuclear power plant that located $30 \mathrm{~km}$ nearby, the probability of giving protest responses from respondents would no longer be significantly influenced by these explanatory variables. The above results show that the probabilities of giving protest responses from respondents are different due to different distances of nuclear power plants. That is, if nuclear power plants were located closer to the places they live, respondents would have stronger willingness pay an extract amount of money to avoid having nuclear power plants in their neighborhood.

According to the econometric results in the sample selection equation, we calculate $\lambda(\bullet)$ (lambda), and add it as an explanatory variable in the elicitation equation. Results in the second step are shown in Table 5. As can be seen, the coefficients of the lambda terms are different in Model 1 and Model 2. In Model 1, the lambda term is significant and positive signed, which suggests that the error terms in the selection and elicitation equations are positive correlated. While in Model 2, the coefficient of lambda term is not statistically different from zero, so that the protest response does not lead to any significant sample selection bias. In other words, under the scenario of constructing a nuclear power plant that located $80 \mathrm{~km}$ in the neighborhood, the protest decision of respondents is interdependent with WTP to replace nuclear power by paying higher electricity tariffs. However, under the scenario of constructing a nuclear power that located $30 \mathrm{~km}$ nearby, the relationship between the protest responses of respondents and WTP is insignificant. That is, the public has stronger willingness pay an extract amount of money when nuclear power plants are located closer. In other words, respondents are quite sensitive to the distance of nuclear facilities

Results of elicitation equation indicate that factors of age, income, education, and job affect the outcome. Besides, these explanatory variables have similar effects in both Model 1 and Model 2. Some previous research showed that gender has an impact on WTP of nuclear facilities or the attitude 
towards the facilities [52,63]. However, the relationship between gender and the WTP is not remarkable in our study. The coefficients of the explanatory variables show that age has a negative impact on the WTP. For example, Kim et al. [5] declared in their study that younger people were less likely to strongly accept nuclear power than older people. Our result corresponds with negative correlations between age and risk rating claimed by Huppe and Janke [80].

Table 5. The econometric results of the two-step sample selection models.

\begin{tabular}{lcccc}
\hline & \multicolumn{2}{c}{ Model 1 $\mathbf{( 8 0} \mathbf{~ k m})$} & \multicolumn{2}{c}{ Model 2 $\mathbf{( 3 0} \mathbf{~ k m})$} \\
\hline Sample selection equation & Estimates & $\boldsymbol{p}$ & Estimates & $\boldsymbol{p}$ \\
\hline Gender & 0.1423 & 0.225 & 0.2054 & 0.350 \\
Age & -0.0096 & 0.156 & -0.0137 & 0.287 \\
Income & 0.1242 & 0.000 & 0.0471 & 0.282 \\
College & 0.3025 & 0.034 & 0.0685 & 0.801 \\
Job & 0.1888 & 0.211 & -0.0016 & 0.995 \\
Risk & -0.4746 & 0.026 & -0.0550 & 0.898 \\
Constant & 0.6807 & 0.010 & 2.2379 & 0.000 \\
Log likelihood & -297.1487 & & -72.8221 & \\
\% Correct predictions & $86.5 \%$ & & $98.1 \%$ & \\
Pseudo R2 & 0.0611 & & 0.0224 & \\
\hline Elicitation equation & Estimates & $\boldsymbol{p}$ & Estimates & $\boldsymbol{p}$ \\
Gender & 0.0339 & 0.267 & 0.0881 & 0.096 \\
Age & -0.0070 & 0.000 & -0.0101 & 0.006 \\
Income & 0.0508 & 0.000 & 0.0364 & 0.000 \\
College & 0.1300 & 0.001 & 0.0888 & 0.003 \\
Job & 0.1151 & 0.003 & 0.0730 & 0.018 \\
Risk & -0.1308 & 0.124 & -0.0155 & 0.771 \\
lambda & 0.8756 & 0.008 & 3.9562 & 0.107 \\
Constant & 0.4765 & 0.000 & 0.7562 & 0.000 \\
Log likelihood & -561.1972 & & -663.0475 & \\
\% Correct predictions & $66.1 \%$ & & $63.9 \%$ & \\
Pseudo R2 & 0.0521 & & 0.0371 & \\
\hline & & & &
\end{tabular}

Table 6 shows the evaluation of respondents' WTP of Model 1 and Model 2. The mean WTP to avoid having a new nuclear power plant within $80 \mathrm{~km}$ is $0.1285 \mathrm{USD} / \mathrm{kWh}$, and it increase to $0.1387 \mathrm{USD} / \mathrm{kWh}$ when the distance is shortened as $30 \mathrm{~km}$. The empirical result shows a higher average WTP to avoid having nuclear power plants located $30 \mathrm{~km}$ nearby than for those located $80 \mathrm{~km}$ in the neighborhood. Assuming that residents are entitled to choose between nuclear power and other clean energies, and more risks would be suffered if respondents lived nearer to nuclear power plants, respondents who live closer to nuclear power plants might have stronger WTP to avoid having nuclear power plants in the neighborhood. The change of WTP for different distances indicates the change of their NIMBY attitudes. 
Table 6. WTP evaluation of Model 1 and Model 2.

\begin{tabular}{cccccc}
\hline Model & Value of mean WTP (USD/kWh) & Standard Error & $\boldsymbol{p}$ & $\mathbf{9 5 \%}$ Confident Interval \\
\hline Model 1 & 0.1285 & 0.0023 & 0.000 & 0.1240 & 0.1330 \\
Model 2 & 0.1387 & 0.0020 & 0.000 & 0.1347 & 0.1426 \\
\hline
\end{tabular}

In order to verify the impact of distance on the WTP, or whether the public shows a greater WTP for the closer nuclear power plants, thereby reflects the syndrome of NIMBY, we conduct a robustness test on results in Model 1 and Model 2. We include both the scenario of nuclear power plants located $80 \mathrm{~km}$ and the scenario of nuclear power plants located $30 \mathrm{~km}$ into one model, and introduce a distance dummy variable (if the nuclear power located $30 \mathrm{~km}$ nearby, the value would be 1). Results of the robustness test are shown in Table 7. The coefficients of the distance variable are significantly positive in results of the selection equation and the elicitation equation, indicating the distance factor affects the public WTP for replacing nuclear power. Therefore, distance is a sensitive factor in the consideration of whether replacing nuclear power or not. Furthermore, under the condition of constructing a nuclear power plant located $30 \mathrm{~km}$ nearby, the probability of willing to pay an extract amount of money for higher electricity prices to replace nuclear power is much higher. The above conclusions are consistent with the results in Model 1 and Model 2.

Table 7. The robust test results.

\begin{tabular}{cccccc}
\hline Sample selection equation & Estimates & $\boldsymbol{p}$ & Elicitation equation & Estimates & $\boldsymbol{p}$ \\
\hline Gender & 0.1542 & 0.135 & Gender & 0.0149 & 0.440 \\
Age & -0.0105 & 0.079 & Age & -0.0053 & 0.000 \\
Income & 0.1084 & 0.000 & Income & 0.0300 & 0.000 \\
College & 0.2547 & 0.043 & College & 0.0866 & 0.000 \\
Job & 0.1478 & 0.265 & Job & 0.0774 & 0.001 \\
Risk & -0.3830 & 0.038 & Risk & -0.0092 & 0.831 \\
Distance & 1.0072 & 0.000 & Distance & 0.1273 & 0.003 \\
Constant & 0.7964 & 0.001 & lambda & 0.3180 & 0.125 \\
Log likelihood & -371.6542 & & Constant & 0.6928 & 0.000 \\
\% Correct predictions & $92.3 \%$ & & Log likelihood & -1228.4354 & \\
Pseudo R2 & 0.1428 & & \% Correct predictions & $64.1 \%$ & \\
- & - & - & Pseudo R2 & 0.0447 & \\
\hline
\end{tabular}

\subsection{Regional Difference of NIMBY Attitude}

Up to now, all nuclear power plants are operating or under construction in coastal areas in China [81]. Therefore, residents in coastal areas have more chances to obtain information about nuclear power than residents in inland areas. We explore whether regions play a role in the NIMBY attitude, and whether public opposition would be more serious for new nuclear power construction in inland areas. Answers to these questions can be found by dividing samples into different groups. Electricity prices are different in regions of China, and respondents would have different baselines of electricity prices in the estimation of WTP. Results in Table 8 show that the mean WTP would be higher in groups of which the local 
electricity prices are higher. Thus, in order to compare the NIMBY attitude among different regions, we need to investigate the variation between respondents' WTP and the present electricity prices.

In order to consider the regional factors, samples are divided into three groups: Group 1 consists of respondents from coastal areas, where the existing nuclear power plants are located; Group 2 consists of respondents from inland areas, where there are no nuclear power plants at present, but would be built in the future according to government planning; Group 1a consists of respondents who currently live near the existing nuclear power plants in coastal areas. The samples in inland and coastal areas in China are illustrated in Figure 2.

Figure 2. Illustration of the samples in inland and coastal areas in China.

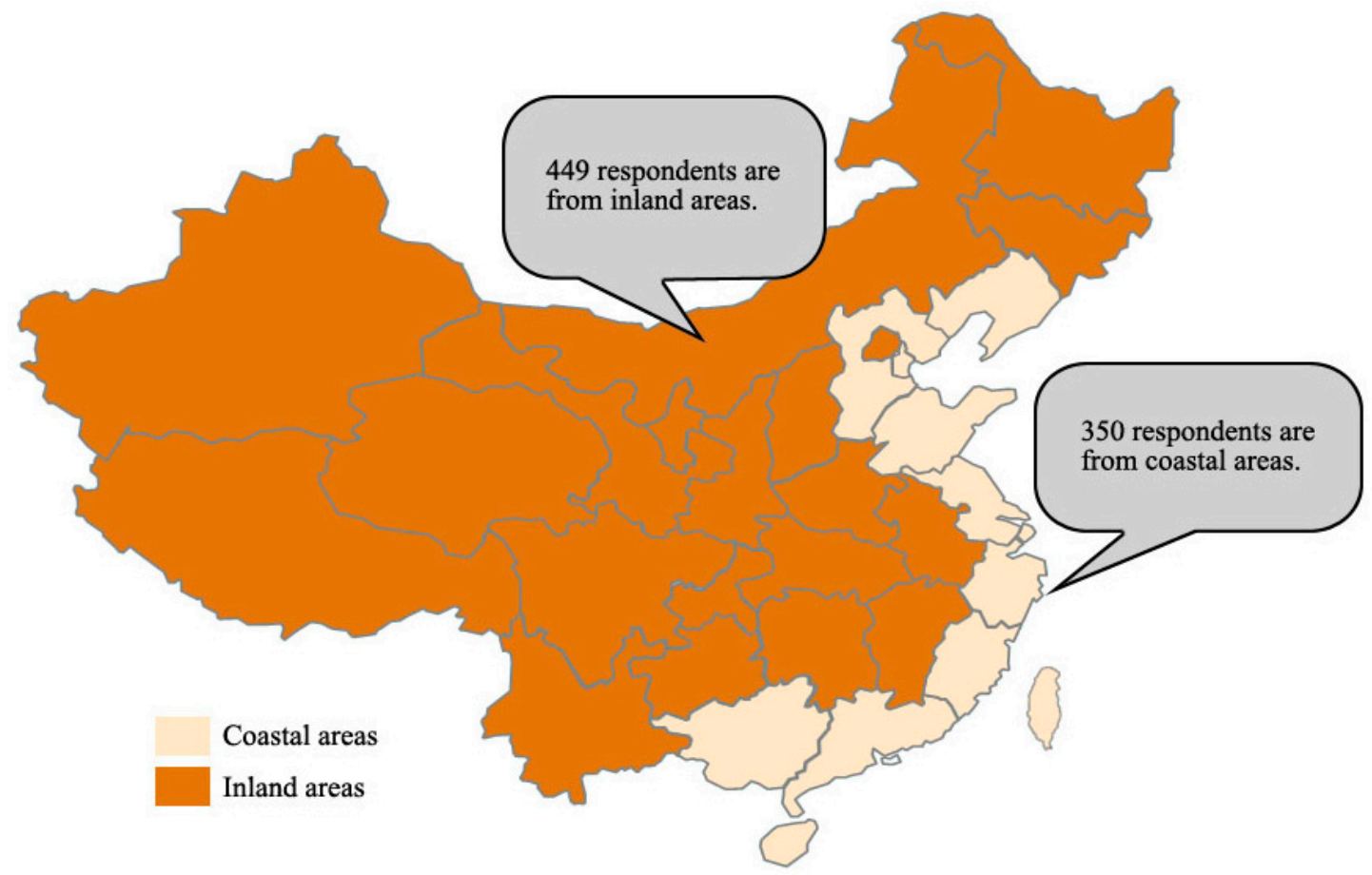

Referring to Table 8, though Group 2 has the lowest mean WTP, it also pays the lowest price for electricity locally. Both Vari. 1 and Vari. 2 suggest that the mean WTP of Group 2 has the largest increase rate: the WTP for nuclear power plants located $80 \mathrm{~km}$ is 1.55 times the local electricity price, and the WTP for nuclear power plants located $30 \mathrm{~km}$ is 1.72 times the local electricity price. Variation of Group 1a is the smallest among the three groups: respondents who currently live near nuclear power plants have the highest WTP, but the local electricity prices are also the highest among the three groups. The mean WTP and the current electricity price of Group 1 are both found between Group 1a and Group 2. From Vari. 1 and Vari. 2, we come to the conclusion that people in inland areas have the strongest NIMBY attitude, and people who live in the vicinity of the existing nuclear power plants have the weakest NIMBY attitude. Results are in accordance with the findings of the previous studies, which indicate that opposition would be the strongest at the planning phase, and then would become weaker before the local projects were proposed or after the NIMBY facility had become operational [55-57]. This result demonstrates that residents have a strong NIMBY attitude towards nuclear power plants, especially those who live in inland areas. 
Table 8. WTP evaluation of Model 3.

\begin{tabular}{ccccccc}
\hline Group & $\begin{array}{c}\text { Current price of } \\
\text { electricity } \\
\text { (USD/kWh) }\end{array}$ & $\begin{array}{c}\text { WTP } \\
\text { (USD/kWh) } \\
\mathbf{( 8 0} \mathbf{~ k m})\end{array}$ & $\begin{array}{c}\text { WTP } \\
(\mathbf{U S D} / \mathbf{k W h}) \\
\mathbf{( 3 0} \mathbf{~ k m})\end{array}$ & Vari. 1 & Vari. 2 & Vari. 3 \\
\hline Group 1a & 0.1033 & 0.1466 & 0.1496 & $41.9 \%$ & $44.8 \%$ & $2.0 \%$ \\
Group 1 & 0.0913 & 0.1376 & 0.1421 & $50.7 \%$ & $55.6 \%$ & $3.3 \%$ \\
Group 2 & 0.0780 & 0.1210 & 0.1345 & $55.1 \%$ & $72.4 \%$ & $11.2 \%$ \\
Total & 0.0820 & 0.1285 & 0.1387 & $56.7 \%$ & $69.1 \%$ & $7.9 \%$ \\
\hline
\end{tabular}

Note: Vari. is the abbreviation of Variation. Variation 1 represents the increase between WTP for $80 \mathrm{~km}$ and the current electricity price; Variation 2 represents the increase between WTP for $30 \mathrm{~km}$ and the current electricity price; Variation 3 is the difference between Variation 1 and Variation 2, which is the variation between WTP for $80 \mathrm{~km}$ and WTP for $30 \mathrm{~km}$.

\subsection{Decay of NIMBY with Longer Distance}

Table 8 shows that the NIMBY attitude decays as distance increases. In an ideal situation, the public tends to accept the safety distance regulated by laws or rules. The NIMBY attitude will apparently decay when the living distance increases to $80 \mathrm{~km}$. Nevertheless, an empirical survey proposes that the NIMBY attitude does decay as distance increases both in coastal and inland areas, but the trend is not obvious. In total, the average of the present electricity price is $0.0820 \mathrm{USD} / \mathrm{kWh}$; and there is a $56.7 \%$ increase of respondents' WTP for nuclear power plants located $80 \mathrm{~km}$, and an additional $7.9 \%$ increase for nuclear power plants located $30 \mathrm{~km}$. Respondents' WTP in inland areas has a larger percentage increase: the mean WTP for nuclear power plants located $80 \mathrm{~km}$ increases by $55.1 \%$ compared to the present electricity price, and the mean WTP for nuclear power plants located $30 \mathrm{~km}$ has an additional increase of $11.2 \%$. As for respondents who live in the vicinity of nuclear power plants, the mean WTP only increases $2 \%$ when the distance is shortened from $80 \mathrm{~km}$ to $30 \mathrm{~km}$.

Variation of WTP for nuclear power plants located $30 \mathrm{~km}$ and $80 \mathrm{~km}$ reflects respondents' sensitivity to distance. The Vari. 3 in Table 8 indicates that people are less sensitive to the distance change if they currently live close to the nuclear power plants. A 2\% difference in Group 1a shows that respondents are indifferent to nuclear power plants located $30 \mathrm{~km}$ or $80 \mathrm{~km}$. In their opinions, they face the same risks within the ranges of $80 \mathrm{~km}$ and $30 \mathrm{~km}$, and the best way is having no nuclear power plants in the neighborhood. Nevertheless, the situation is different in inland areas. People in inland areas focus more on the specific location of the plant. An $11.2 \%$ difference apparently shows their sensitivity of distance. Therefore, the location of the new plant is more important in solving the problem of NIMBY in inland areas. Hence, in order to decrease the effect of NIMBY attitudes, strategies should be differentiated in different regions.

The gap between WTP for nuclear power plants located $80 \mathrm{~km}$ and the present electricity price in Vari. 1 shows that distance in regulation or in actual situation is inconsistent with the accepted distance in public. Zweifel et al. [63] showed that the safety distance is $95 \mathrm{~km}$ for public. They studied the public WTP for the insurance of living near nuclear power plants, and found that the pay fell to zero with the distance of $95 \mathrm{~km}$. Assuming the decrease of WTP has a linear relationship with the increase in distance [63], we can figure out the distance where the WTP equals the present electricity price. Results show that the pay falls to the present electricity price when the distance is $354 \mathrm{~km}$. Even though $80 \mathrm{~km}$ 
is the largest distance for nuclear monitor in regulations, the safety distance that the public can accept is far greater than this.

Previous studies suggested monetary compensations to reduce the NIMBY effect. In Taiwan, the aggregate WTP for a decrease in the nuclear energy ratio is $\$ 675$ million New Taiwan Dollar (NTD) [75]. In the case of Korea, the yearly public WTP is 278 million USDS [76]. These WTP estimates provide preliminary information about compensation. We can estimate the compensation for residents who live near nuclear power plants by calculating the yearly public WTP. For more than 75 million people who are living near nuclear power plants in the distance of $80 \mathrm{~km}$ [21], the yearly WTP should be $\$ 1150.9$ million. Result in our paper is much greater compared to the countries mentioned above. Since the CVM is based on an assumed situation, the real amount of compensation could be even larger than the assumed value considering the implementation process of nuclear power policy. Thus, the compensation estimated by the WTP only reflects the minimum quantity, and the amount of compensation would show an increasing trend in China with the growing number of nuclear power plants.

\section{Conclusions and Policy Implications}

Nuclear power has become an important energy source in the context of deteriorating energy and environmental security. It is particularly crucial for China to restructure its energy layout and solve the environmental problems. At the meeting of the State Energy Commission held on 18 April 2014, Premier $\mathrm{Li}$ announced that more nuclear power plants will be launched on the eastern coast. However, public acceptance is still a major barrier for further nuclear power development worldwide after the Fukushima nuclear disaster. The Chinese government is more than prudent in re-launching the nuclear power projects. The purpose of this paper is to provide references for future nuclear power policy in China.

Our study finds that the NIMBY attitude is an important potential impediment to nuclear power development, which could even impact the power structure in China. Most respondents prefer to pay more for other clean energies to replace nuclear power plants in the neighborhood. By comparing the WTP for avoiding nuclear power plants nearby with the current electricity price, we find that there is an increase of $56.7 \%$ of WTP for a nuclear power plant located $80 \mathrm{~km}$, and an increase of $69.1 \%$ of WTP for a nuclear power plant located $30 \mathrm{~km}$. Results indicate that there exists a strong NIMBY attitude among the public. Therefore, the public attitude cannot be ignored in choosing the new nuclear power locations. Social-economic characteristics have impacts on the public NIMBY attitude: age has a negative impact on the WTP, and income has a positive impact on the WTP. We also find that civil servants, who have a higher WTP than others, play an important role in determining the research outcome. Unlike previous studies, the effect by gender is not taken into consideration in view of the lack of knowledge of nuclear power in China.

Regional difference also has an effect on the NIMBY syndrome. People in inland regions have the strongest NIMBY attitude towards nuclear power plants, and people who live near nuclear power plants have the weakest NIMBY attitude. This implies that the problem of public opposition would be more serious when nuclear power expands to inland regions. Since the apparent "attitude gap" between "before" and "during" the planning of a local project was a key problem [57], the government should pay more attention to the public attitude at the planning phase of a new nuclear power project. Therefore, 
actions should be taken to enhance the information interchange among the public, government and nuclear enterprises.

The analysis about the decay of NIMBY suggests that the safety distance that public can accept is much farther than $80 \mathrm{~km}$. People in inland areas are more concerned about the location of nuclear power plants and are more sensitive to the distance. Their WTP increases when the distance is shortened from $80 \mathrm{~km}$ to $30 \mathrm{~km}$. The safety distance suggested by nuclear power regulations cannot be easily accepted. For monetary compensation, the yearly compensation would be no less than $\$ 1150.9$ million in total for people who live near nuclear power plants that located $80 \mathrm{~km}$ nearby. Considering that people in inland regions are more sensitive to distance, monetary compensation based on distance could be considered in these regions.

However, monetary compensation has its limitations, and cannot fundamentally solve the issue. Individuals may ease their opposition to the proposed facilities, if they have been properly compensated for accepting the costs; however, the effects of compensation are not uniform across all types of facilities [82]. According to the previous studies, compensation for nuclear power plants cannot work in every case. Based on the survey of CPPNP, we find that the public in China lacks the cognition of nuclear power and relative regulations, which is easily influenced by the media. This indicates the importance of communication with honest information between the public and the stakeholders [76]. Thus, a transparent system for information exchanging about nuclear power development should be built, so that the local dwellers can participate in the decision-making about the location and provision of a nuclear power plant. Public participation does not mean being persuaded, but the right to deny or adjust the project. In this way, more trust can be given to the government, and the public can treat nuclear power with a more rational manner [83].

Results indicate that decision makers should pay more attention to the public attitude than ever before due to the existence of NIMBY attitude towards building a new nuclear power plant in the neighborhood. Although our study contributes to the literature on nuclear energy policy by exploring the public NIMBY attitude of nuclear power plants, and by providing policymakers with compensation suggestions, there are also limitations in the study. Due to the limitation of the CPPNP survey, it only estimates public WTP to avoid having nuclear power plants in the neighborhood by introducing two kinds of distance. Therefore, a series of additional surveys are required to explore the spatial factor and to find the relationship between the NIMBY syndrome and distance. In addition, further investigations on each region's characteristics that affect the public WTP are required. More data on acknowledge about nuclear power can help us obtain more results from a broader perspective. Periodical surveys about respondents' attitudes toward nuclear power plants in the neighborhood can show the time factor of WTP by further study on WTP in the same regions during the planning process or after the nuclear power plant has become operational. Therefore, deep and comprehensive research will give us more profound and valuable information as well as insights for nuclear energy policies. In addition, the data used in this paper are obtained by asking the questions of WTP. WTA could be estimated without the need to refer to an alternative "clean" power source, therefore, we will consider estimating the willingness to Accept (WTA) in the future research. 


\section{Acknowledgments}

We would like to express our sincere gratitude to the three anonymous referees for their insightful and constructive comments. This article is supported by National Natural Science Foundation of China (Grant Nos. 71303199 and 71373218), Ministry of Education Foundation of China (Grant Nos. 13YJC790123 and 13JZD010), Soft Science Plan Funded Project of Fujian Province (Grant No. 2014R0088), Natural Science Foundation of Fujian Province (Grant No. 2014J01269), Social Science School of Fujian (Grant No. 2014B100), Social Science School of Xiamen (Grant No. [2014]15), Major Program of the National Social Science Foundation of China (Grant No. 13\&ZD167), Youth Project of the National Social Science Foundation of China (Grant No. 12CTJ014), General Project of the Social Science Foundation of Fujian Province (Grant No. 2014B100) and the College Students Innovation and Entrepreneurial Training Plan of Xiamen University (Grant Nos. DC2013041 and DC2013135).

\section{Author Contributions}

Chuanwang Sun gave the framework of this research and made substantial contribution to the study design. Nan Lyu constructed the model and provided a wide range of support throughout the study. Xiaoling Ouyang gave some core advices, checked the whole paper, and revised the manuscript. All authors have read and approved the final manuscript.

\section{Appendix}

The purpose of CPPNP is to explore public perceptions and attitudes toward nuclear power plant construction in the context of restarting the large-scale nuclear construction program in China. The topic has policy implications because the general public would be more sensitive to nuclear power after the Fukushima nuclear disaster in 2011. The survey of CPPNP, launched by China Center for Energy Economics Research at Xiamen University once to twice a year from 2013, is a nationwide face-to-face survey focuses on the public perception of nuclear power. The face-to-face interview is conducted because some questions are relatively professional and technical which require oral explanations. More importantly, the face-to-face interview is a good way to enhance communication with interviewees and convey information required by the Contingent Valuation Method (CVM). For instance, the interviewees could obtain information about substitutes and budget constraints reminders as suggested by the NOAA Panel [84]. Particularly, the pre-test survey is conducted in order to identify issues related to questionnaire design, statement expressions, payment vehicle, the transmission of energy policy and bid amount, and conduct the pre-pilot study and evaluation.

The questionnaire can be divided into four parts. The first part is the introduction, which includes information of the current price level of electricity, the average household budget for electricity expenditure, information channels of nuclear power development. Meanwhile, the first part also introduces the general background and characteristics of the different forms of power generation, in order to make interviewees clearly understand the situation of nuclear power development. The second part is the personal understanding or perception and concern of nuclear power. For example, the most worried risks of nuclear power, the most effective measures to reduce public concerns and attitudes about the development of nuclear power in China. The third part is the introduction of the contingent valuation scenario and 
dichotomous questions. According to the two-step sample selection method, we first explore whether the public is willing to pay and identify the protesters, then we investigate how much are they willing to pay for electricity tariffs [74]. The fourth part is composed of demographic and social-economic questions, including the respondents' gender (this question is not included in the questionnaire, because the answers can be obtained by visual observations and communications), age, education, income and job, etc. We can obtain explanatory variables of the WTP by asking the above questions.

Specifically, in the third part mentioned above, the sequential questions are as follows:

Question 1: In order to meet the rising demand for electricity and reduce emissions, we assume that the government plans to construct a nuclear power plant (located $80 \mathrm{~km} / 30 \mathrm{~km}$ in the neighborhood). If you disagree with the nuclear power construction, you are entitled to convince the government to use other higher-cost clean energies to replace nuclear power. However, such substitution would inevitably increase electricity price. Are you willing to pay higher electricity tariffs in order to substitute nuclear power?

Yes, I am willing to pay. No, I am unwilling to pay.

Question 2: According to the results of Question 1, Question 2 is divided into two parts.

If the respondents are willing to replace nuclear power, we will ask the first bid amount (Chinese Yuan) for electricity tariffs. It should be noted that the unit of Chinese Yuan (CNY) for electricity tariffs is adopted as the payment vehicle, because the respondents are more familiar with and sensitive to electricity price. The above settlement is also determined by the results of the pre-survey. If the respondents were willing to make the first bid, we would continue to ask if they were willing to pay the second higher bid amount for electricity tariffs. If not, we would ask if they were willing to pay the second lower bid amount.

If the respondents were unwilling to replace nuclear power, we will ask them reasons. If the respondents display apathetic indifference towards the construction of nuclear power, we can regard their WTP as genuine zeros. If the respondents hold the views that the government should be responsible for the issue, or they think that they have already paid enough costs or taxes and therefore refuse to pay the proposed additional charges on electricity tariffs, we can regard their responses as protest responses. In this way, we can distinguish the protest responses from the genuine zero responses by their motives behind the answers, and then construct a sample selection model. According to Calia and Strazzera [74], a sample selection model with the protest responses should be preferred to the model without protest responses, since it takes into account the uncertainty about the estimates of the WTP for the public good.

Meanwhile, in order to enhance respondents' understanding of contingent valuation scenario, the following sentences are emphasized in both the questionnaire and the face-to-face survey when asking dichotomous questions: "Please answer questions according to your personal budget and the sensitivity to the risk of nuclear power. Your actual WTP will help to slow down or even stop the construction of nuclear power plants in your neighborhood". The settlement above makes the contingent valuation scenario more understandable. In other words, if the respondents were in a relatively more convinced scenario, their responses would be more accurate. For example, the government is considering implementing a policy, and public responses will be used to help inform that decision [85]. In this context, individuals would have incentives to truly respond as long as they believe that their responses can probabilistically influence government decisions [86]. Table A1. presents major questions about the NIMBY syndrome and the WTP. 
Table A1. Major questions about the NIMBY syndrome and the WTP.

\begin{tabular}{|c|c|c|}
\hline Category & Questions & Answers \\
\hline $\begin{array}{l}\text { Sample } \\
\text { selection } \\
\text { questions }\end{array}$ & $\begin{array}{l}\text { In order to meet the rising demand for electricity and } \\
\text { reduce emissions, we assume that the government plans to } \\
\text { construct a nuclear power plant nearby }(80 \mathrm{~km} / 30 \mathrm{~km}) \text {. If } \\
\text { you disagree with the nuclear power construction, you are } \\
\text { entitled to convince the government to use other } \\
\text { higher-cost clean energies to replace nuclear power. } \\
\text { However, such substitution would inevitably increase } \\
\text { electricity price. Are you willing to pay higher electricity } \\
\text { tariffs in order to substitute nuclear power? }\end{array}$ & $\begin{array}{l}\text { Yes, I am willing to pay. } \\
\text { No, I am unwilling to pay. }\end{array}$ \\
\hline $\begin{array}{l}\text { The WTP } \\
\text { elicitation } \\
\text { questions }\end{array}$ & $\begin{array}{l}\text { If the answer of the sample selection question is "Yes, I am } \\
\text { willing to pay", we will continue to ask: how much are } \\
\text { you willing to pay (first bid amount) for the electricity } \\
\text { tariff (Chinese Yuan)? }\end{array}$ & $\begin{array}{l}\text { If the respondents were } \\
\text { willing to make the first } \\
\text { bid, we would continue to } \\
\text { ask if they were willing to } \\
\text { pay the second higher bid } \\
\text { amount for electricity } \\
\text { tariffs. If not, we would } \\
\text { ask if they were willing } \\
\text { to pay the second lower } \\
\text { bid amount. }\end{array}$ \\
\hline $\begin{array}{c}\text { Protest } \\
\text { responses } \\
\text { questions } \\
\text { (distinguishing } \\
\text { protest } \\
\text { responses from } \\
\text { genuine zero } \\
\text { responses) }\end{array}$ & $\begin{array}{l}\text { If the answer of the sample selection question is "No, I am } \\
\text { unwilling to pay". }\end{array}$ & $\begin{array}{l}\text { There is no need to replace } \\
\text { nuclear power because it } \\
\text { has no negative impact } \\
\text { on me. } \\
\text { The government should } \\
\text { address the issue. } \\
\text { I have paid enough costs } \\
\text { and taxes, and do not } \\
\text { want to increase } \\
\text { electricity tariffs. }\end{array}$ \\
\hline
\end{tabular}

$\begin{array}{cl}\begin{array}{c}\text { Demographic } \\ \text { and }\end{array} & \text { Age; Educational level; } \\ \begin{array}{c}\text { social-economic } \\ \text { questions }\end{array} & \text { Annual personal income; Job. }\end{array}$

Taking notes according to the specific circumstances.

Note: It should be noted that other questions are also included in the survey of CPPNP, which comprehensively investigates the public attitudes about nuclear power. We do not present all questions in the questionnaire due to the space limitation. Other questions, which are designed for exploring related nuclear policy, are used for our further studies.

\section{Conflicts of Interest}

The authors declare no conflict of interest. 


\section{References}

1. Hartmann, P.; Apaolaza, V.; D’Souza, C.; Echebarria, C.; Barrutia, J.M. Nuclear power threats, public opposition and green electricity adoption: Effects of threat belief appraisal and fear arousal. Energy Policy 2013, 62, 1366-1376.

2. Laes, E.; Meskens, G.; van der Sluijs, J.P. On the contribution of external cost calculations to energy system governance: The case of a potential large-scale nuclear accident. Energy Policy 2011, 39, 5664-5673.

3. Ramana, M.V. Nuclear power and the public. Bull. At. Sci. 2011, 67, 43-51.

4. Visschers, V.H.M.; Wallquist, L. Nuclear power before and after Fukushima: The relations between acceptance, ambivalence and knowledge. J. Environ. Psychol. 2013, 36, 77-86.

5. Kim, Y.; Kim, M.; Kim, W. Effect of the Fukushima nuclear disaster on global public acceptance of nuclear energy. Energy Policy 2013, 61, 822-828.

6. Gamson, W.A.; Modigliani, A. Media discourse and public opinion on nuclear power: A constructionist approach. Am. J. Sociol. 1989, 95, 1-37.

7. Kemp, R. Why not in my backyard? A radical interpretation of public opposition to the deep disposal of radioactive waste in the United Kingdom. Environ. Plan. A 1990, 22, 1239-1258.

8. Wolsink, M. Wind power and the NIMBY-myth: Institutional capacity and the limited significance of public support. Renew. Energy 2000, 21, 49-64.

9. Devine-Wright, P. Public engagement with large-scale renewable energy technologies: Breaking the cycle of NIMBYism. Clim. Chang. 2011, 2, 19-26.

10. He, G.; Mol, A.P.J.; Zhang, L.; Lu, Y. Public participation and trust in nuclear power development in China. Renew. Sustain. Energy Rev. 2013, 23, 1-11.

11. International Energy Statistics. Available online: http://www.eia.gov/cfapps/ipdbproject/ IEDIndex3.cfm (accessed on 4 September 2014).

12. Kunsch, P.L.; Friesewinkel, J. Nuclear energy policy in Belgium after Fukushima. Energy Policy 2014, 66, 462-474.

13. Srinivasan, T.N.; Gopi Rethinaraj, T.S. Fukushima and thereafter: Reassessment of risks of nuclear power. Energy Policy 2013, 52, 726-736.

14. China's National Energy Administration (CNEA). Available online: http://zfxxgk.nea.gov.cn/ auto82/201401/t20140124_1756.htm (accessed on 4 September 2014).

15. The State Council. Available online: http://www.gov.cn/ldhd/2012-10/24/content_2250357.htm (accessed on 4 September 2014).

16. World Nuclear Association. Nuclear Power in China, Updated March 2012. Available online: http://www.world-nuclear.org/ (accessed on 4 September 2014).

17. Lu, D. The Current Status of Chinese Nuclear Power Industry and Its Future. Available online: http://www.jsm.or.jp/ejam/Vol.2.No.1/GA/12/article.html (accessed on 15 October 2014).

18. World Nuclear Association. Nuclear Power in China. Available online: http://www.world-nuclear.org/ info/Country-Profiles/Countries-A-F/China--Nuclear-Power/ (accessed on 16 August 2014).

19. CEIC China Database. Available online: http://www.ceicdata.com/countries/china (accessed on 16 August 2014). 
20. World Nuclear Association. World Energy Needs and Nuclear Power. Available online: http:// www.world-nuclear.org/info/Current-and-Future-Generation/World-Energy-Needs-and-NuclearPower/ (accessed on 16 August 2014).

21. Butler, D. Nuclear safety: Reactors, residents and risk. Nature 2011, 472, 400-401.

22. China's National Energy Administration. 2014 Guidance for Energy. Available online: http://zfxxgk.nea.gov.cn/auto82/201401/t20140124_1756.htm (accessed on 16 August 2014).

23. Quan, S.W.; Zeng, Y.C.; Huang, B. Public perception and acceptance of nuclear power in Beijing, China. Soc. Sci. Beijing 2012, 5, 55-60. (In Chinese)

24. Schively, C. Understanding the NIMBY and LULU Phenomena: Reassessing Our Knowledge Base and Informing Future Research. J. Plan. Lit. 2007, 21, 255-266.

25. Greenberg, M.R. NIMBY, CLAMP, and the Location of New Nuclear-Related Facilities: U.S. National and 11 Site-Specific Surveys. Risk Anal. 2009, 29, 1242-1254.

26. Refineries and petrochemicals plants. Available online: http:/www.bp.com/en/global/corporate/ about-bp/company-information/group-organization/downstream/refineries-and-petrochemicalsplants.html (accessed on 16 August 2014).

27. Qu, G.H. PX Projects and Their Effect on Sustainability of Chinese Oil Refining Industry. Sino Glob. Energy 2013, 7, 1-7. (In Chinese).

28. Singapore integrated manufacturing site. Available online: http://www.exxonmobil.com/APEnglish/Files/Combined_Site_Brochure_FINAL.pdf (accessed on 16 August 2014).

29. Steenhof, P.A.; Fulton, W. Scenario development in China's electricity sector. Technol. Forecast. Soc. Chang. 2007, 74, 779-797.

30. Romanello, V.; Salvatores, M.; Schwenk-Ferrero, A.; Gabrielli, F.; Vezzoni, B.; Rineiski, A.; Fazio, C. Sustainable Nuclear Fuel Cycles and World Regional Issues. Sustainability 2012, 4, 1214-1238.

31. Van der Zwaan, B.C.C. Nuclear energy: Tenfold expansion or phase-out? Technol. Forecast. Soc. Chang. 2002, 69, 287-307.

32. Pearce, J.M. Limitations of Nuclear Power as a Sustainable Energy Source. Sustainability 2012, 4, 1173-1187.

33. Lozano, R.L.; Hernández-Ceballos, M.A.; Adame, J.A.; Casas-Ruíz, M.; Sorribas, M.; Miguel, E.G.S.; Bolívar, J.P. Radioactive impact of Fukushima accident on the Iberian Peninsula: Evolution and plume previous pathway. Environ. Int. 2011, 37, 1259-1264.

34. Wittneben, B.B.F. The impact of the Fukushima nuclear accident on European energy policy. Environ. Sci. Policy 2012, 15, 1-3.

35. Kim, Y.; Kim, W.; Kim, M. An international comparative analysis of public acceptance of nuclear energy. Energy Policy 2014, 66, 475-483.

36. Stoutenborough, J.W.; Sturgess, S.G.; Vedlitz, A. Knowledge, risk, and policy support: Public perceptions of nuclear power. Energy Policy 2013, 62, 176-184.

37. Dalla Valle, A.; Furlan, C. Diffusion of nuclear energy in some developing countries. Technol. Forecast. Soc. Chang. 2014, 81, 143-153.

38. Guidolin, M.; Guseo, R. A nuclear power renaissance? Technol. Forecast. Soc. Chang. 2012, 79, 1746-1760.

39. Aoki, M.; Rothwell, G. A comparative institutional analysis of the Fukushima nuclear disaster: Lessons and policy implications. Energy Policy 2013, 53, 240-247. 
40. Homma, T.; Akimoto, K. Analysis of Japan's energy and environment strategy after the Fukushima nuclear power plant accident. Energy Policy 2013, 62, 1216-1225.

41. Heffron, R.J. Nuclear new build in the United States 1990-2010: A three state analysis. Technol. Forecast. Soc. Chang. 2013, 80, 876-892.

42. Heffron, R.J. Nuclear energy policy in the United States 1990-2010: A federal or state responsibility? Energy Policy 2013, 62, 254-266.

43. Roh, S.; Kim, W. How can Korea secure uranium enrichment and spent fuel reprocessing rights? Energy Policy 2014, 68, 195-198.

44. Siegrist, M.; Visschers, V.H.M. Acceptance of nuclear power: The Fukushima effect. Energy Policy 2013, 59, 112-119.

45. Bird, D.K.; Haynes, K.; van den Honert, R.; McAneney, J.; Poortinga, W. Nuclear power in Australia: A comparative analysis of public opinion regarding climate change and the Fukushima disaster. Energy Policy 2014, 65, 644-653.

46. Park, E.; Ohm, J.Y. Factors influencing the public intention to use renewable energy technologies in South Korea: Effects of the Fukushima nuclear accident. Energy Policy 2014, 65, 198-211.

47. Rosa, E.A.; Dunlap, R.E. The Pools-Poll trends: Nuclear power: Three decades of public opinion. Public Opin. Q. 1994, 58, 295-324.

48. Van der Horst, D. NIMBY or not? Exploring the relevance of location and the politics of voiced opinions in renewable energy siting controversies. Energy Policy 2007, 35, 2705-2714.

49. Zhang, L.; Tong, X. Analysis of public NIMBY attitude and its factors. Soc. Sci. Res. 2014, 1, 105-111. (In Chinese)

50. Pineda-Solano, A.L.; Carreto-Vazquez, V.H.; Mannan, M.S. The Fukushima Daiichi Accident and its Impact on Risk Perception and Risk Communication. Chem. Eng. Trans. 2013, 31, 517-522.

51. Ansolabehere, S.; Konisky, D.M. Public Attitudes toward Construction of New Power Plants. Public Opin. Q. 2009, 73, 566-577.

52. Hüppe, M.; Weber, J. Effects of Distance, Age and Sex upon Attitudes toward Nuclear Power Plants: An empirical study: Untersuchung zu Einstellungen gegenüber Atomkraftwerken in Abhängigkeit von Wohndistanz, Alter und Geschlecht. Zentralblatt für Hygiene und Umweltmedizin 1999, 202, 331-344.

53. Davidson, L.M.; Baum, A.; Collins, D.L. Stress and Control-Related Problems at Three Mile Island1. J. Appl. Soc. Psychol. 1982, 12, 349-359.

54. Baum, A.; Gatchel, R.J.; Schaeffer, M.A. Emotional, behavioral, and physiological effects of chronic stress at Three Mile Island. J. Consult. Clin. Psychol. 1983, 51, 565-572.

55. Balzekiene, A.; Rinkevicius, L. Global issues, local solutions: Sociological analysis of public risk perceptions and attitudes to nuclear waste disposal. Socialinial Mokslai 2002, 37, 42-47.

56. Wolsink, M. Entanglement of Interests and Motives: Assumptions behind the NIMBY-theory on Facility Siting. Urban Studies 1994, 31, 851-866.

57. Bell, D.; Gray, T.; Haggett, C. The 'Social Gap' in Wind Farm Siting Decisions: Explanations and Policy Responses. Environ. Polit. 2005, 14, 460-477.

58. Mitchell, R.C.; Carson, R.T. Property Rights, Protest, and the Siting of Hazardous Waste Facilities. Siting of Hazardous Facilities. Am. Econ. Rev. 1986, 76, 285-290. 
59. Marsh, D.; Mkwara, L.; Scarpa, R. Do Respondents' Perceptions of the Status Quo Matter in Non-Market Valuation with Choice Experiments? An Application to New Zealand Freshwater Streams. Sustainability 2011, 3, 1593-1615.

60. Del Saz-Salazar, S.; Hernández-Sancho, F.; Sala-Garrido, R. The social benefits of restoring water quality in the context of the Water Framework Directive: A comparison of willingness to pay and willingness to accept. Sci. Total Environ. 2009, 407, 4574-4583.

61. Carson, R.T. Constructed Markets. In Measuring the Demand for Environmental Quality; Braden, J.B., Kolstad, C.D., Eds.; Elsevier: Amsterdam, The Netherlands, 1991; pp. 121-160.

62. Gawande, K.; Jenkins-Smith, H. Nuclear Waste Transport and Residential Property Values: Estimating the Effects of Perceived Risks. J. Environ. Econ. Manag. 2001, 42, 207-233.

63. Zweifel, P.; Schneider, Y.; Wyss, C. Spatial effects in willingness-to-pay: The case of nuclear risks. Available online: http://www.actuaries.org/ASTIN/Colloquia/Zurich/Zweifel_Schneider_Wyss.pdf (accessed on 28 September 2014).

64. Ferreira, S.; Gallagher, L. Protest responses and community attitudes toward accepting compensation to host waste disposal infrastructure. Land Use Policy 2010, 27, 638-652.

65. Zhou, L.; Peng, X.; Guan, E.; Zhang, Y.; Huang, S. Public NIMBY attitude survey and WTA estimate of waste incineration facility. Ecol. Environ. 2012, 12, 174-177. (In Chinese)

66. Yamane, F.; Matsushita, K.; Ohgaki, H.; Asano, K. Study Plans Concerning Monetary Evaluation of Mitigation Measures for the Fukushima Daiichi Accident. Energy Procedia 2013, 34, 937-944.

67. Choi, K.S.; Lee, K.J.; Lee, B.W. Determining the value of reductions in radiation risk using the contingent valuation method. Ann. Nucl. Energy 2001, 28, 1431-1445.

68. Pelekasi, T.; Menegaki, M.; Damigos, D. Externalities, NIMBY syndrome and marble quarrying activity. J. Environ. Plan. Manag. 2012, 55, 1192-1205.

69. Ouyang, X.; Lin, B. Impacts of increasing renewable energy subsidies and phasing out fossil fuel subsidies in China. Renew. Sustain. Energy Rev. 2014, 37, 933-942.

70. Dziegielewska, D.; Mendelsohn, R. Does "No" mean "No"? A protest methodology. Environ. Resour. Econ. 2007, 38, 71-87.

71. Haab, T. Nonparticipation or Misspecification? The Impacts of Nonparticipation on Dichotomous Choice Contingent Valuation. Environ. Resour. Econ. 1999, 14, 443-461.

72. Ramajo-Hernández, J.; del Saz-Salazar, S. Estimating the non-market benefits of water quality improvement for a case study in Spain: A contingent valuation approach. Environ. Sci. Policy 2012, $22,47-59$.

73. Heckman, J.J. Sample selection bias as a specification error. Econometrica 1979, 47, 153-161.

74. Calia, P.; Strazzera, E. A sample selection model for protest votes in contingent valuation analyses. Statistica 2001, 61, 473-485.

75. Liao, S.Y.; Tseng, W.C.; Chen, C.C. Eliciting public preference for nuclear energy against the backdrop of global warming. Energy Policy 2010, 38, 7054-7069.

76. Jun, E.; Joon Kim, W.; Hoon Jeong, Y.; Heung Chang, S. Measuring the social value of nuclear energy using contingent valuation methodology. Energy Policy 2010, 38, 1470-1476.

77. Petition for rulemaking to improve emergency planning regulation. Available online: http://www.nirs.org/reactorwatch/emergency/petitionforrulemaking22012.pdf (accessed on 12 September 2014). 
78. IAEA Safety Standards for protecting people and the environment. Available online: http:// www-pub.iaea.org/MTCD/publications/PDF/Pub1534_web.pdf (accessed on 12 September 2014).

79. Zhao, B.; Qiu, L. Selection of Emergency Release Source Term and Partition of EPZ in the Chinese PWR NPP. Radiat. Prot. Bull. 2003, 2, 6-9. (In Chinese)

80. Hüppe, M.; Janke, W. The nuclear plant accident in chernobyl experienced by men and women of different ages: Empirical study in the years 1986-1991. Anxiety Stress Coping 1994, 7, 339-355.

81. China National Energy Administration. Available online: http://www.nea.gov.cn/2012-10/24/ c_131927804.htm (accessed on 12 September 2014).

82. Ansolabehere, S. Public Attitudes toward America's Energy Options: Insights for Nuclear Energy; CANES Publications: Cambridge, MA, USA, 2007.

83. Sun, C.; Zhu, X. Evaluating the public perceptions of nuclear power in China: Evidence from a contingent valuation survey. Energy Policy 2014, 69, 397-405.

84. Arrow, K.; Solow, R.; Protney, P.R.; Leamer, E.E.; Radner, R.; Schuman, H. Report of the NOAA panel on contingent valuation. 9 May 1993, pp. 4601-4614. Available online: http:// www.cbe.csueastbay.edu/ alima/courses/4306/articles/NOAA\%20on\%20contingent\%20valuation \%201993.pdf (accessed on 28 September 2014).

85. Carson, R.T. Contingent Valuation: A Practical Alternative when Prices Aren't Available. J. Econ. Perspect. 2012, 26, 27-42.

86. Poe, G.L.; Vossler, C.A. Consequentiality and Contingent Values: An Emerging Paradigm. In The International Handbook on Non-Market Environmental Valuation; Bennett, J. Ed.; Edward Elgar Publishing: Cheltenham, UK, 2011; pp. 122-141.

(C) 2014 by the authors; licensee MDPI, Basel, Switzerland. This article is an open access article distributed under the terms and conditions of the Creative Commons Attribution license (http://creativecommons.org/licenses/by/4.0/) 